\title{
O invariável, \\ a norma e o \\ desconhecido: \\ a emergência da arquitetura moderna brasileira em debate*
}

\author{
Clara Bonna Pignaton**
}

\begin{abstract}
Resumo O presente artigo expõe os conflitos decorrentes da emergência da linguagem moderna no Brasil no campo da arquitetura através de debates ocorridos em veículos públicos como jornais e congressos. A discussão travada entre arquitetos e pensadores como Flávio de Carvalho, Mario de Andrade e Le Corbusier elucidam as preocupações da época, sejam elas a construção de uma identidade nacional, o progresso, a normatização, bem como a dialética entre a racionalidade e as emoções.
\end{abstract}

Palavras-chave: arquitetura moderna, progresso, norma.

Lo invariable, la norma y lo desconocido: el surgimiento de la arquitectura brasileña moderna en debate

Resumen El presente artículo expone los conflictos derivados de la emergencia del lenguaje moderno en Brasil en el campo de la arquitectura a través de debates ocurridos en vehículos públicos como periódicos y congresos. La discusión trabada entre arquitectos y pensadores como Flávio de Carvalho, Mario de Andrade y Le Corbusier elucidan las preocupaciones de la época, sean ellas la construcción de una identidad nacional, el progreso, la normatización, así como la dialéctica entre la racionalidad y las emociones.

Palabras clave: arquitectura moderna, progresso, norma.
The invariable, the norm and the unknown: the emergence of modern Brazilian architecture in debate

\begin{abstract}
This article presents the conflicts arising from the emergence of modern language in Brazil in the field of architecture through debates in public vehicles such as newspapers and congresses. The discussion between architects and thinkers such as Flávio de Carvalho, Mario de Andrade and Le Corbusier elucidate the concerns of the time, being them the construction of a national identity, progress, normalization, as well as the dialectic between rationality and emotions.
\end{abstract}

Keywords: modern architecture, progresso, norm. 
0

s diálogos acerca da arquitetura moderna se iniciam timidamente no correr da década de 20. Em se tratando da difusão de tais ideias no contexto nacional, o manifesto do arquiteto russo Gregori Warchavchik (1925) ocupa um papel relevante em termos de construção do campo ${ }^{1}$. Suas concepções estavam fortemente alinhadas ao movimento moderno francês proposto por Le Corbusier em Por uma arquitetura (1923), quando este fixou boa parte dos preceitos e da crítica moderna: superação da atividade decorativa, urgência de estender a racionalidade de construção das máquinas aos campos de atuação da arquitetura e da vida social, "lógica" como premissa, e "economia e comodidade" como valores. Ademais, Warchavchik pregava a negação absoluta do estilo, tanto na imitação passadista quanto na classificação da própria prática contemporânea. A arquitetura moderna não poderia se edificar sobre a noção de estilo, deveria ser apenas racional aliada aos "princípios da grande indústria", o que equivale à adesão ao ideal de estandardização e produção em série.

Muito embora o manifesto levantasse o debate em torno do tema da arquitetura moderna paralelamente ao processo de renovação estética em curso na cidade de São Paulo, pouquíssimas foram suas expressões até aquele momento. A Semana de 22 não havia impulsionado o movimento como ocorria nos outros campos das artes. Na ocasião fora apenas o espanhol Antônio Garcia Moya a trazer uma linguagem dissonante das convenções estabelecidas; seus desenhos se conectavam tanto à arquitetura mediterrânea, quanto aos templos pré-colombianos e do Egito antigo ou às mesquitas de taipa no norte africano, além de ser possível identificar traços da arquitetura marajoara. Tais aproximações foram possíveis pelo caráter primitivo que Ihe dão suas linhas retas e as estruturas geométricas maciças. Mesmo sem definição de quais seriam os materiais utilizados, Moya elimina os adornos e elementos postiços incorporados à estrutura, o que confere a sua obra um aspecto de modernidade.

A despeitos de alguns episódios, nada de realmente convincente para época havia aparecido em termos de modernidade arquitetônica, talvez tenha sido esta a lacuna que Flávio de Carvalho procurou ocupar quando em 1927 participou do concurso público para construção do Palácio do Governo de São Paulo. A figura polêmica do engenheiro-artista Flávio de Carvalho é pouco debatida na historiografia da arquitetura, muito embora tenha sido de extrema relevância por tencionar o campo no diálogo com a linguagem estética proposta pelo movimento de vanguarda. Suas provocações

* Pesquisa financiada com apoio do CNPQ através de bolsa de doutorado.

** Clara Bonna Pignaton é Arquiteta e Urbanista, Pesquisadora da Universidade Federal da Bahia.

10 manifesto foi publicado primeiramente no Correio da Manhã, Rio de Janeiro, em 01 de novembro de 1925. ganham centralidade na argumentação do presente artigo.

Sob o pseudônimo "Efficacia", Flávio de Carvalho apresentou em meio a frontões, arabescos e anjos graciosos a impassível sobriedade de uma nova arquitetura. Seu trabalho é prontamente reconhecido como a primeira manifestação de arquitetura moderna no Brasil pelos jornais, que exaltam a novidade como uma "nota de imprevisto" na sociedade paulistana. Contra a aparência imitativa dos projetos ecléticos e neoclássicos, "Efficacia" lança sua arquitetura não menos monumental. Na robustez em que se apresenta, sobressaíam-se as proporções volumétricas e as superfícies lisas 


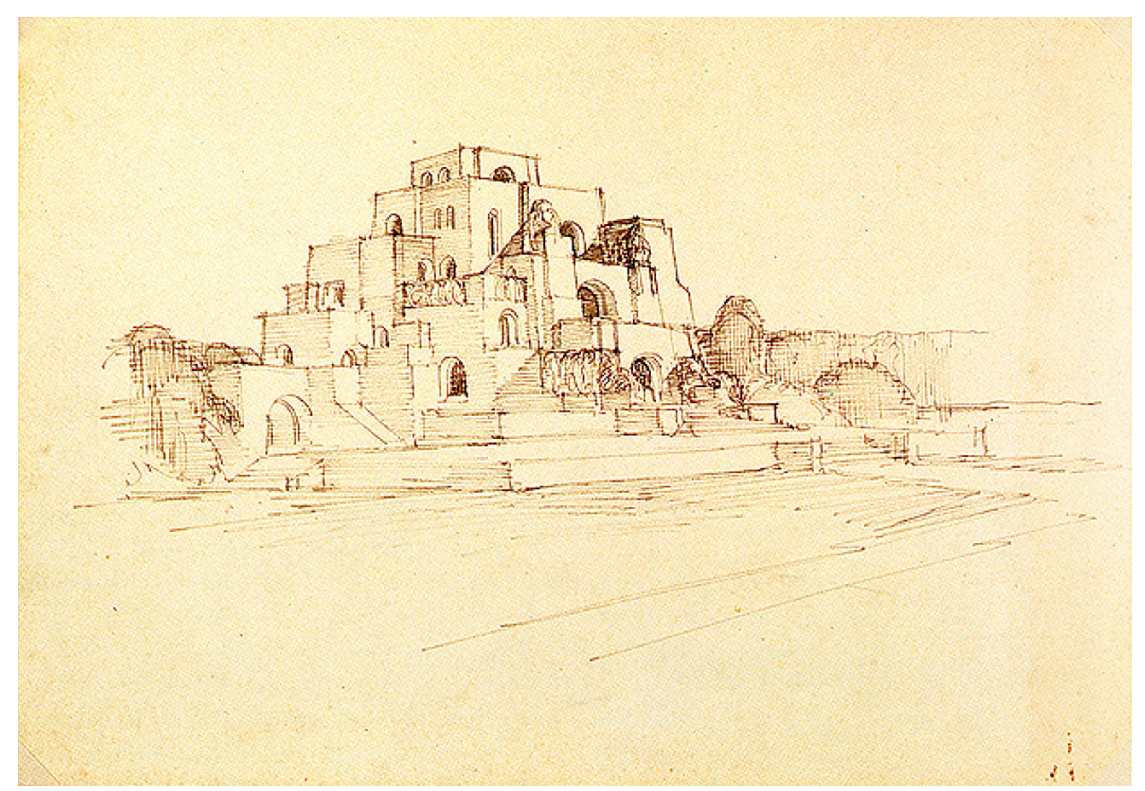

Figura 1 (topo): Antonio Garcia

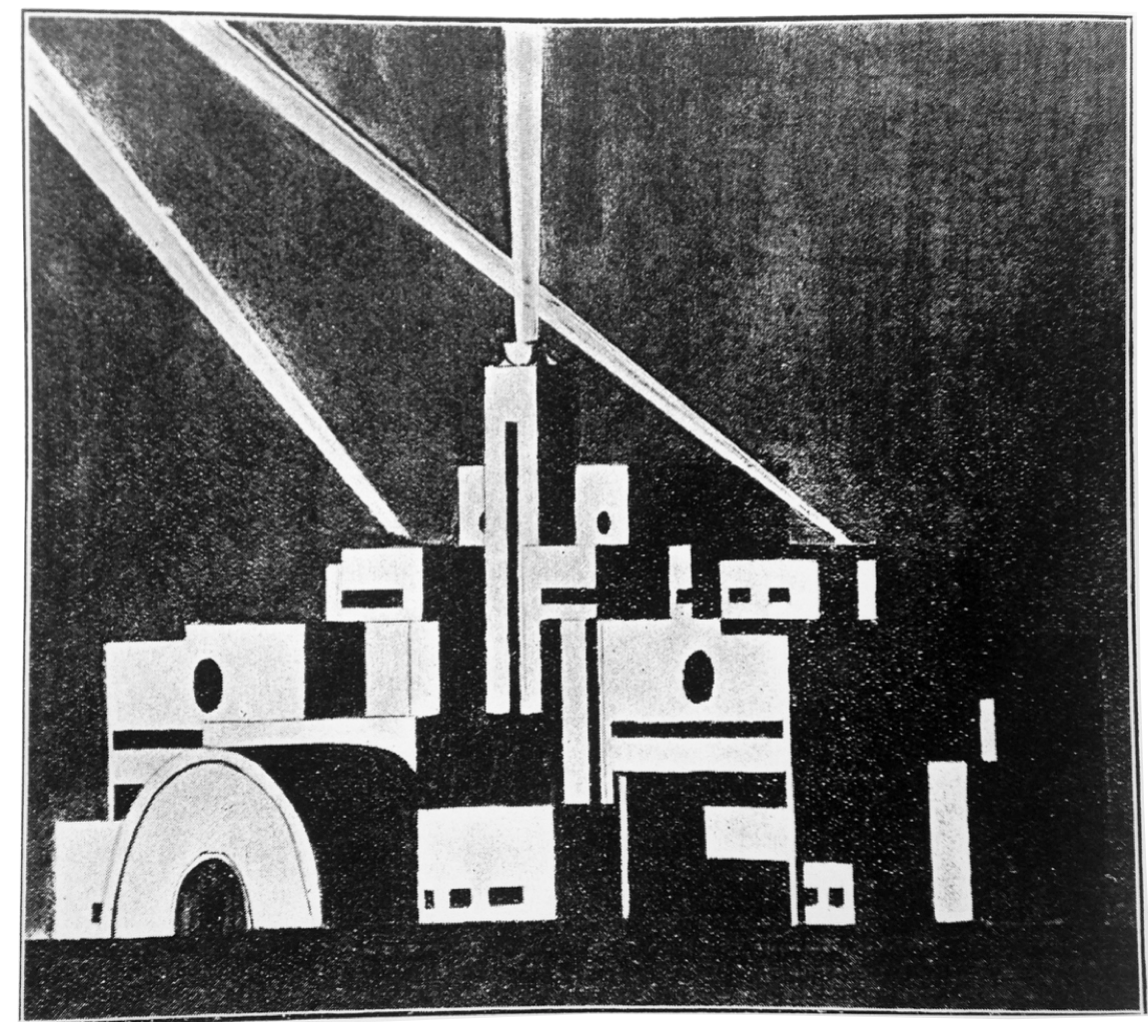
Moya, Monumento, 1922. Fonte: Amaral, 1998.

Figura 2 (embaixo): Flávio de Carvalho, Projeto Palácio do Governo, 1928. Fonte: Fundo FC/Cedae. 
uma vez que o recurso dos retoques ornamentais havia sido eliminado. Seguindo à risca as diretivas modernas, o concreto armado estabelece as linhas gerais e a estética do edifício.

Por outro lado, a parte a austeridade, o prédio possuía terraços onde estariam plantadas espécies da mata brasileira em espaços que comportam até três metros de terra, bases de aviações onde os campos de aterrisagem estariam equipados com plataformas movediças e catapultas para o lançamento de aviões-caça, equipamentos estes que estavam a serviço de atender as funções do programa. A provocativa tônica carvalhiana era atuar, através da doutrina moderna, uma evidente teatralidade calculada.

Ora, o engenheiro-artista que "se atira assim tão violentamente contra a rotina" (AINDA..., 1928) levanta uma polêmica discussão na imprensa. E logo Mario de Andrade, sempre atento ao contexto mais amplo de reflexão das artes, propõe-se ao exercício de análise do projeto numa série de artigos intitulada "Arquitetura Moderna" no Diário Nacional. O poeta, que procede com extrema cautela em seus dizeres para não ser confundido com um militante da doutrina moderna cuja arquitetura geralmente não o convencia, tece uma crítica um tanto ambígua. Ora problematiza uma simetria excessiva e rija na distribuição dos volumes, o que teria escravizado o artista. Logo, o anuncia como um "soco profético": "é lógico e claro. É nobre e monumental. Dá impressão de força consciente, e não tem peso" (ANDRADE M., 1928a). A resposta de Carvalho não tardaria muito, no mesmo jornal ele esmiuçaria suas escolhas bélicas e também as formais como "expressão" das "necessidades" do edifício, justificando a simetria pelo equilíbrio. Foi acusado por Mario de Andrade de uma "ironia dolorosa", e justamente por ela Carvalho tentou explicitar a crise geral da ordem aristocrático-burguesa para além das questões formais. E assim o faz por uma perspectiva antitradicionalista e libertária, no sentido de tentar, pela provocação, romper com as convenções que confinam as formas de ação do homem.

Dois dias após a réplica de Flávio de Carvalho a Mario de Andrade, a capa do Diário Nacional exibia sob o título "As novas tendências da Arquitetura", imagens das casas de Walter Gropius e Le Corbusier na exposição de arquitetura em Stuttgart (1927). O artigo, que nada dizia a respeito da exposição a não ser sobre a autoria dos projetos, propõe-se a defender a necessidade de adequação da arquitetura a uma época em tudo dominada pela máquina. $O$ texto afirmava que a arquitetura deveria se transformar como ocorre com a moda dos vestuários e independentemente daqueles espíritos conservadores apegados aos valores de tradição e presos ao passado. A arquitetura muda e "evolui", "foi realista com os gregos, sensual e brilhante com os bizantinos, mística e torturada com os góticos, pesada e preocupada com o problema da eternidade, no Egito" (AS NOVAS..., 1928). Seguindo a cartilha da arquitetura moderna, de maneira bem explicativa, o artigo reiterava os argumentos de Mario de Andrade de que já existiam pelo mundo ruas inteiras com tais exemplares de arquitetura e que a transformação era um destino inevitável:

O arranha-céu, a fábrica são os dois protótipos da arquitetura legítima, acomodada com o espírito da vida contemporânea. Nada de enfeites decorativos nem de imitações arrebicadas. Nitidez, claridade, comodidade, higiene. O mesmo espírito que fez o avião, a fábrica, o automóvel, faz as casas únicas possíveis hoje. Damos aqui exemplos dessa arquitetura contemporânea. (ANDRADE M., 1928a) 
Existe um quadro crítico alinhado às tendências internacionais que se propõe ao exercício de denunciar categoricamente um contexto nacional "miseravelmente atrasado" em termos da "arte de construir casas". Como se vê, é notória a repetição do vocabulário e das expressões nos debates travados nos jornais da época, jornais estes que passam a se ocupar de apontar para uma sociedade conservadora, patriarcal e reticente a mudanças.

Logo o debate sobre a arquitetura moderna se amplia por inúmeros fatores no período que se segue. Um deles é a passagem de Le Corbusier pelo país em 1929, quando proferiu algumas palestras sobre a "revolução arquitetural contemporânea" e as soluções do urbanismo para as grandes cidades modernas. Neste momento as ideias corbusianas de pureza e racionalização já estavam plenamente absorvidas pela cartilha modernista internacional. Uma racionalização capaz de retirar das construções os véus inúteis que mascaravam as "leis do universo", para que nelas fossem apreendidas as ordens da natureza que irrefutavelmente comovem os homens. Le Corbusier trata de um retorno à ordem, cujas leis são de conhecimento e de fascinação universal, e uma herança dos ensinamentos clássicos, gregos. Universal no sentido de aproximação a um cânone absoluto, livre do acidental e das contingências para que restasse então apenas o essencial, isto é, o "elemento puro", "invariante" e "geral". Precisamente, "generalizar" significaria para Corbusier o "fim mais elevado do espírito" (JEANNERET; OZENFANT, 2005, p. 66) uma vez que a "invariante" presente na plástica pura das formas primárias afetava "fisiologicamente" (LE CORBUSIER, 2013, p.7) os sentidos do homem. Para Le Corbusier, a arquitetura é um "fenômeno de emoção", capaz de espiritualizar pois alcança a objetividade na matéria sobre a qual se projeta uma ordem, portanto, sendo também uma "pura criação do espírito" (LE CORBUSIER, 2013, p.10). Tal objetividade alcançada seria depositária da coletividade humana, uma vez que é universal e não dá margem às tendências individualistas e burguesas do romantismo.

Seus projetos são clichês de capas de jornal e é Flávio de Carvalho, acompanhado de Geraldo de Ferraz, que se encarrega de entrevistá-lo para o Diário da Noite num encontro que ocorreu na casa do anfitrião Paulo Prado. A matéria publicada se concentra em grande parte nas perguntas elaboradas pelos correspondentes do jornal, de maneira que ela se torna muito mais reveladora das questões que afligiam o próprio Flávio de Carvalho do que esclarecedora acerca das formulações teóricas do ilustre arquiteto suíço e de sua escola. Le Corbusier, um pouco irônico, sorri dizendo que nelas havia assunto para um livro de arquitetura:

$1 a$ - Acha que arquitetura é um problema filosófico? 2a - Deve a arquitetura ser lógica? Que é lógica? 3a - Deve a arquitetura ter cor? 4a - Qual o fator predominante: a cor, a forma ou a ideia funcional? $5 a$ - Que é que constitui o agradável na cor e na forma? 6a - É esse agradável subjetivo ou objetivo? 7a - Como introduzir o fator psíquico na arquitetura? 8a - Deve-se ou não sacrificar a ideia da estrutura pelo fator psíquico? 9a - Deve o desejo de progredir sujeitar-se ao homem ou o homem sujeitar-se ao desejo de progredir?

Sobre Urbanismo. 1a-Deve o homem submeter-se às forças da natureza ou deve pesquisar novos problemas, criar novos ambientes? $2 a$ - Deve a cidade ser uma máquina eficiente de viver ou deve o homem sacrificar a eficiência pelas vontades caóticas do inconsciente? (...) 8 a - Deve uma cidade ser alimentada coletivamente 
2 Na mesma página do Diário Nacional acima citado [01 de mar. de 1929] na qual Flávio de Carvalho trata da relação da "Arquitetura e vida" e das "divisões da arquitetura" aqui abordadas, foi publicada também uma nota com os pontos principais da conferência do surrealista Benjamin Péret em São Paulo; "Apollinaire e o cubismo", a revolta anárquica do Dada, a espontaneidade e a revelação do inconsciente, as relações do surrealismo com a psicanálise de Freud, etc. Curiosamente, a diagramação do jornal colocava a nota sobre Péret dentro da entrevista de Flávio de Carvalho. ou não? 9a - Deve-se ou não alterar o sistema social de uma nação para melhorar a vida do homem na cidade? (ARTE..., 1929)

Carvalho está preocupado em confrontar o "fator psíquico" com aquele mental e lógico na arquitetura. Além da expressão de uma época, a arquitetura era para ele uma arte que o homem utiliza, portanto, vinculada tanto à comodidade, quanto aos "prazeres estéticos". Uma vez que a "emotividade estética" (CARVALHO, 1929a) é correlata ao contexto cultural de cada um, a arquitetura assume também uma função social. Não é por simples questão de predominância que Carvalho pergunta sobre forma, cor e função. Segundo seu raciocínio, a tensão em torno do fator psíquico se coloca na arquitetura em termos de forma e a cor, sendo a forma a que proporciona bem-estar físico e moral, e a cor, o bem-estar intelectual. Uma compreende o campo de ação do engenheiro e a outra recai no domínio da psicanálise, e o arquiteto é exatamente o engenheiro-artista que trabalha entre os campos (CARVALHO, 1929a).

Há ainda nas perguntas de Carvalho a Le Corbusier uma indagação sobre os limites do progresso técnico pela via do subjetivo e do psíquico, o que pode parecer uma contradição sobretudo porque em tempos em que as grandes descobertas científicas definiam o estado mental dos homens, a psicanálise surge enquanto ciência. Freud pretendia atender a critérios científicos para fazer valer a psicanálise como tal. Sem dúvida, a perspectiva de entrada de Carvalho no campo da psicanálise provinha de suas leituras freudianas, mas também estava impregnada com a abordagem surrealista da psicanálise através da arte. Em São Paulo, meses antes, Carvalho havia sido apresentado ao casal Benjamin Péret e Elsie Houston e ali iniciado sua incursão pelo surrealismo ${ }^{2}$. Fator ainda mais definitivo seria seu contato com a Antropofagia. Mario de Andrade havia introduzido Carvalho à cena cultural paulista, e a conexão com Oswald de Andrade e os demais antropófagos teria sido imediata. O vínculo que só se estreitaria com o tempo, estabeleceu-se incialmente em razão de uma crítica feita por Carvalho à exposição de Tarsila do Amaral, onde analisa um "sistema de condensação simbólica" das obras em paralelo ao mecanismo libidinoso de Freud (CARVALHO, 1929a).

Em relação às perguntas, Le Corbusier, apesar da "objetividade universal subconsciente" (LE CORBUSIER, 1929) da escola purista da qual fazia parte, contesta que a consciência do homem é "multiforme". Diante disso, ao arquiteto caberia o trabalho de colocar em ordem os elementos essenciais e os dados concretos para obter a harmonia necessária que satisfaça os desejos e aspirações do homem. Trata-se de uma questão de técnica e aí está a lógica, independentemente da civilização maquinista em que viviam. "Ao arquiteto, que procura incessantemente a perfeição, impõe-se a tarefa de contentar com a técnica o ambiente em que se colocam as consciências". Tal ambiente, sendo uma casa ou a cidade, com excessiva mecanização da vida ou, ao contrário, enquanto lugar de completa desorganização "produz no animal humano uma reação que se traduz em neurastenias e doenças nervosas" (LE CORBUSIER, 1929). Assim Carvalho o indaga: $O$ arquiteto seria então capaz de despertar no homem-habitante sentimentos tão diversos quanto a angústia? Mas Le Corbusier prefere manter a arquitetura apenas sob o "sistema solar". A conversa teria perpassado outros assuntos trazidos por Carvalho, como o sistema soviético e a filosofia de Krishnamurti. Na matéria escrita por Ferraz contém o relato de que as "massas" não interessavam ao grande arquiteto já que as elites técnicas sobrepunham suas opiniões. 
Deste encontro saiu o célebre epíteto dado a Flávio de Carvalho por Le Corbusier: um "revolucionário romântico". Carvalho, por sua vez, tempos depois o teria chamado de um "clássico da arquitetura" (CARVALHO, 1930a) contrariando a opinião de muitos. Clássico no sentido de conduzir a arquitetura ao mecanismo involuntário da repetição (estandardização) e, assim, perder qualquer traço do caráter revolucionário que pudesse ter existido, tornando-se classicista. Noutras palavras, em Carvalho a repetição faz de um revolucionário um mero classicista. Oswald de Andrade, reitera categoricamente: "Como Flávio disse hoje aos jornais, Le Corbusier não é para nós, senão o último grande arquiteto burguês, (...) demonstrando mais estreito espírito burguês cristão" (ANDRADE O.,1930b). A questão radical para Carvalho punha-se nos termos disparatados de uma nova sociedade, que orquestrada pela velocidade das descobertas científicas, ainda permanecia quase dominada pelas velhas tendências da repetição irrefletida, presas ao tipo. Não foi por acaso sua pergunta a Le Corbusier sobre a necessidade de se alterar o sistema social contemporâneo a eles, Carvalho estava certo que sim. Acreditava ainda que a solução proposta por Le Corbusier à "sociedade maquinista", enquanto categoria social, não deu cabo das transformações que uma produção arquitetônica de "massa" procurou alcançar (pela técnica) no contexto histórico do primeiro pós-guerra. Dali, Carvalho parte para a especulação sobre o que seria, no contexto brasileiro, um "novo sistema social", isto é, um "sistema social eficiente" (CARVALHO, 1930c).

O esforço passou a ser o de elaboração de uma doutrina estética adequada ao século, cuja concepção arquitetônica fosse derivada da ciência, portanto, "uma arquitetura livre do passado" conduzida pela lógica e pelo raciocínio para alcançar o bem-estar e a eficiência. Até aí nada de novo. A irreverência de sua teoria da arquitetura é a incorporação que faz da psicanálise e da antropofagia. Carvalho se aproveita do IV Congresso Pan Americano de Arquitetos (1930) para novamente travar um debate polêmico na mídia de massa como um veículo para fixar suas visões. Agora, ele parte para o Rio de Janeiro como delegado antropófago para apresentar a curiosa tese, "A cidade do Homem Nu".

Através da Antropofagia, Carvalho reafirma o sentido agudo de se pensar o legado cultural universal de modo dialético e dialógico com o nacional. Jamais por uma perspectiva simplista de assimilação submissa, mas por uma "devoração crítica" e irônica que vem a tempo e a propósito, profanada, sem hierarquia, expropriada. Tanto mais, com Flávio de Carvalho, a antropofagia tida como um movimento literário reaparece sob bases científicas, e Oswald de Andrade não só consente, como parte em defesa de seu delegado, afinal, mesmo tendo sido vinculado tardiamente ao movimento, Carvalho "sempre foi um fervoroso adepto da aventura pessoal e, portanto, um antropófago autêntico" (ANDRADE O.,1930b). A tese sobre a cidade do homem nu introduz o critério climatério à questão do urbanismo, que é para o poeta exatamente o ponto de vista antropofágico, e diante disso enaltece a atuação de seu delegado ao dizer que "a Antropofagia é um movimento de ação e pesquisa que não pode parar nem ante às grandes realizações russas e americanas atuais, nem ante a formidável contribuição de Le Corbusier" (ANDRADE O.,1930b).

Ambos enxergavam tanto "Vers un Architetcture" quanto o "Código da Família" russo ainda pertencentes ao quadro cristão, na medida em que instauravam uma modernização tão niveladora quanto a filosofia escolástica durante todo o ciclo cristão. 
Para estes antropófagos, o homem moderno permanecia aprisionado aos tabus religiosos, operando um mecanismo dogmático de repetição que lhe fez abdicar do raciocínio, causando-Ihe paralisia e apatia, tirando-lhe a curiosidade e a capacidade de questionar. Ora, para um antropófago, ciência e religião eram irreconciliáveis; o único modo seria realmente sair do círculo que contrariava as leis fisiológicas do homem e recalcava suas "melhores tendências".

O homem perseguido pelo ciclo cristão, embrutecido pela filosofia escolástica, exausto com 1500 anos de monotonia recalcada, aparece no nosso século como uma máquina usada, repetindo tragicamente os mesmos movimentos ensinados por Aristóteles. O ciclo cristão destaca-se sobre as outras religiões por ter dominado o homem mais civilizado. Mas este homem civilizado acorda para ver no ciclo cristão a destruição de si mesmo. As outras religiões são narcóticos idênticos. O burguês venera o passado e os acontecimentos do passado tal como o concebeu uma tradição decaída: ele repete o passado sem saber por que; ele aos poucos destrói o seu organismo, as possibilidades de progresso e mudança.

Nos dias de hoje a fadiga é manifesta, o homem, máquina do classicismo moldado pela repetição contínua nos feitos seculares do cristianismo, não mais pode aturar a monotonia dessa rotina. Ele perecerá asfixiado na seleção lógica, pelo mais eficiente, pelo homem natural. (CARVALHO, 1930b)

O homem burguês que se prende ao passado da repetição contínua está fadado à monotonia, dela apenas o progresso e a mudança o liberariam. Progresso não é para Carvalho, a razão pela qual o homem se prende ao tipo e à estandardização mas, ao contrário, a saída de tal condição. Não que a civilização tenha adormecido por completo durante o ciclo cristão - Carvalho relembra Galileu, Newton e Darwin; aparições episódicas de "gênio" que traduzem o desejo tão primitivo da procura, de irromper do senso comum e avançar, nada menos que "violentas manifestações de romantismo, uma espécie de ressurgimento da alma recalcada do homem oprimido" (CARVALHO, 1930a). Em relação a seu tempo e como antropófago, Carvalho propõe a saída pela psicanálise sem, contudo, aprisionar-se ao rigor teórico. O "sistema libidinoso de Freud" (CARVALHO, 1930d) forneceu os meios de compreensão das tendências recalcadas do homem e apresentou possibilidades de manejá-las através da compreensão lógica das coisas. Tal mecanismo permitiria ao homem liberar-se dos tabus da civilização em que vivia e despi-lo dos dogmas que o agasalhavam para deixá-lo nu.

Sem deus, sem matrimônio e sem propriedade privada, tendo abandonado os princípios da sociedade burguesa cuja falência fora decretada, seria possível formular um novo sistema social que tirasse proveito da energia latente do homem por tantos anos recalcada. Socialismos e comunismos não consideraram a natureza do homem pela via da psicanálise e esta era a razão, para Carvalho, de serem sistemas nocivos: por repetirem as velhas tendências escolásticas (CARVALHO, 1930e). O delegado antropófago propunha um novo mecanismo de "renovação constante do espírito" em que o homem nu estaria livre para raciocinar sem entraves. Livre para mudar, caminhar, pesquisar e progredir de modo que utilizasse seu maior rendimento para aumentar a eficiência da vida e da coletividade. Progredir era a condição do homem, e eis o que significa o progresso: precisamente a ânsia por "penetrar o desconhecido" que reconecta o homem nu ao mundo pré-burguês e anterior ao recalque cristão. 
Mas quais seriam os mecanismos possíveis para progredir? Claramente se dariam através da antropofagia: "o novo movimento científico antropofágico tem como base a pesquisa e exaltação do entusiasmo do homem perante as coisas da natureza, sem os "tabus" do passado"(CARVALHO, 1930d).

Carvalho explica o movimento antropofágico em termos de ideologia, cujos princípios partem da retomada do homem biológico de Nietzsche, interpretado pelos poetas como o homem primitivo livre da catequese ocidental. "O homem, como ele aparece na natureza, selvagem, com todos os seus desejos, toda a sua curiosidade intacta e não reprimida. O homem que totemiza o seu tabu, tirando dele o rendimento máximo" (CARVALHO, 1930b). Não que o homem estaria completamente livre dos tabus, apenas recriaria uma nova ordem para eles, raciocinada para novos rendimentos; "o homem que procura transformar o mundo não métrico no mundo métrico" (CARVALHO, 1930b). A arte e a arquitetura seriam funções desse desejo de mudança, e para compreendê-las bem era preciso passar pela etapa de destruição de valores do passado arraigados há séculos na perniciosa cultura escolástica. O novo sistema social convoca o abandono do culto ao passado.

Para melhorar a vida do homem na cidade era fundamental alterar o sistema social; assim Carvalho responderia à pergunta feita por ele mesmo a Le Corbusier. No Congresso Pan Americano dos Arquitetos apresenta então sua proposta para uma cidade americana: sem o peso das tradições seculares, a cidade do homem nu era "geográfica e climatérica",

30 delegado antropófago obviamente não se concentra em propor diretrizes urbanísticas concretas para a construção de uma cidade. Encenando o papel do arquiteto moderno funcionalista que dita as leis de organização para um organismo urbano, Carvalho especula sobre um zoneamento adequado à eficiência da vida urbana, cujas funções, um tanto fantasiosas, conferem à tese o tom excêntrico que lhe convém: "A cidade será a imagem matemática do homem livre (...) As necessidades do homem serão concêntricas por ser a disposição concêntrica mais igualmente acessível a todos. (...) A cidade do homem nu é dominada pelo centro de pesquisas, é este a única autoridade constituída; ele seleciona e distribui, de acordo com o critério científico, (...) ele é o deus mutável, o deus em movimento contínuo, o deus símbolo do desejo maravilhoso de penetrar no desconhecido. (...) O centro de ensino e orientação do homem é um anel anexo ao centro de pesquisas. O centro de gestação, máquina imensa onde a vida [é] estudada". (CARVALHO, 1930b). não mais a "cidade-fortim da conquista" (CARVALHO, 1930b) ${ }^{3}$. Certamente, Carvalho causou enorme rebuliço, afinal, como ele mesmo afirma, sua atuação era dissonante, "nada tinha a ver com a tendência clássica e pacífica dos congressistas" (CARVALHO, 1930f). Um dos principais temas oficiais em debate no Congresso tratava da necessidade de incrementar no âmbito que envolve o campo do ensino e dos poderes públicos, uma prática da Arquitetura de caráter nacional, como uma resposta ao cumprimento de sua finalidade social moderna. O assunto da arte nacional era clamado, sem, contudo, colocar barreiras ao espírito moderno, mas como uma função própria dele. No entanto, é notório que Carvalho não concordasse com a configuração dada ao tradicional e ao regional naquele congresso em que José Mariano Filho representava a expressão mais forte de orientação da arquitetura brasileira, e os planos de Alfred Agache fossem protagonistas nas propostas urbanísticas. Para um antropófago, a única tradição possível estaria na mata virgem e no caráter viril do elemento telúrico.

Fiz oposição, também, tenazmente à defesa do nosso chamado "Patrimônio artístico", alegando que o nosso patrimônio só é considerado patrimônio da conquista colonial em diante; isto é, da introdução da civilização ocidental, nefasta, monótona, reprimindo a virilidade tropical do ambiente, recalcando e destruindo a tendência do índio, em vez de estudá-la e de criar para ela um mecanismo de máximo rendimento.

Fui contra a incompreensão do Sr. Alfredo Agache, (...) [que] desconhece a maraviIhosa arte dos marajoaras, dos guaranis, as civilizações maias e astecas, a ponto de colocar em plena praça do Castelo um mausoléu com frisos copiados do Parthenon! Nós tropicais, mestiços de negros e portugueses, com uma probabilidade gigantesca de possuir uma civilização única - o nosso orgulho de amanhã - não podemos nos sujeitar a essa imposição francesa. (...) Não queremos mais ver o gigantesco capital jônico na abertura solene de um Congresso Pan-Americano. (CARVALHO, 1930f) 
"A série "Arquitetura Colonial" foi publicada no Diário Nacional entre os dias 23 e 26 de ago. de 1928.

Figura 3: Flávio de Carvalho, Projeto para o Farol de Colombo, 1928. Fonte: Fundo FC/CEDAE.
Elementos da arquitetura pré-colombiana já haviam sido utilizados por Carvalho numa expressão moderna para o anteprojeto do concurso do Farol de Colombo em São Domingos (1928). Ali, ele deixou transparecer que o velho impasse das vanguardas artísticas em conciliar as tendências nacionais e internacionais estava resolvido e superado na sua arquitetura. De um jeito ou de outro, Carvalho batia de frente para que tal orientação "espiritual" da arquitetura na América não fosse ditada pelo neocolonial ou qualquer estilo historicista, justamente porque o recurso estilístico ainda era o meio de se fazer arquitetura nas cidades brasileiras, bastando lembrar que o emblemático edifício Martinelli havia sido inaugurado no ano anterior (1929). Ainda que o debate sobre o caráter nacional na arquitetura se fizesse necessário na altura do Congresso, ele não começou ali; já havia se tornado público poucos anos antes em críticas escritas por Mario de Andrade para o Diário Nacional ${ }^{4}$.

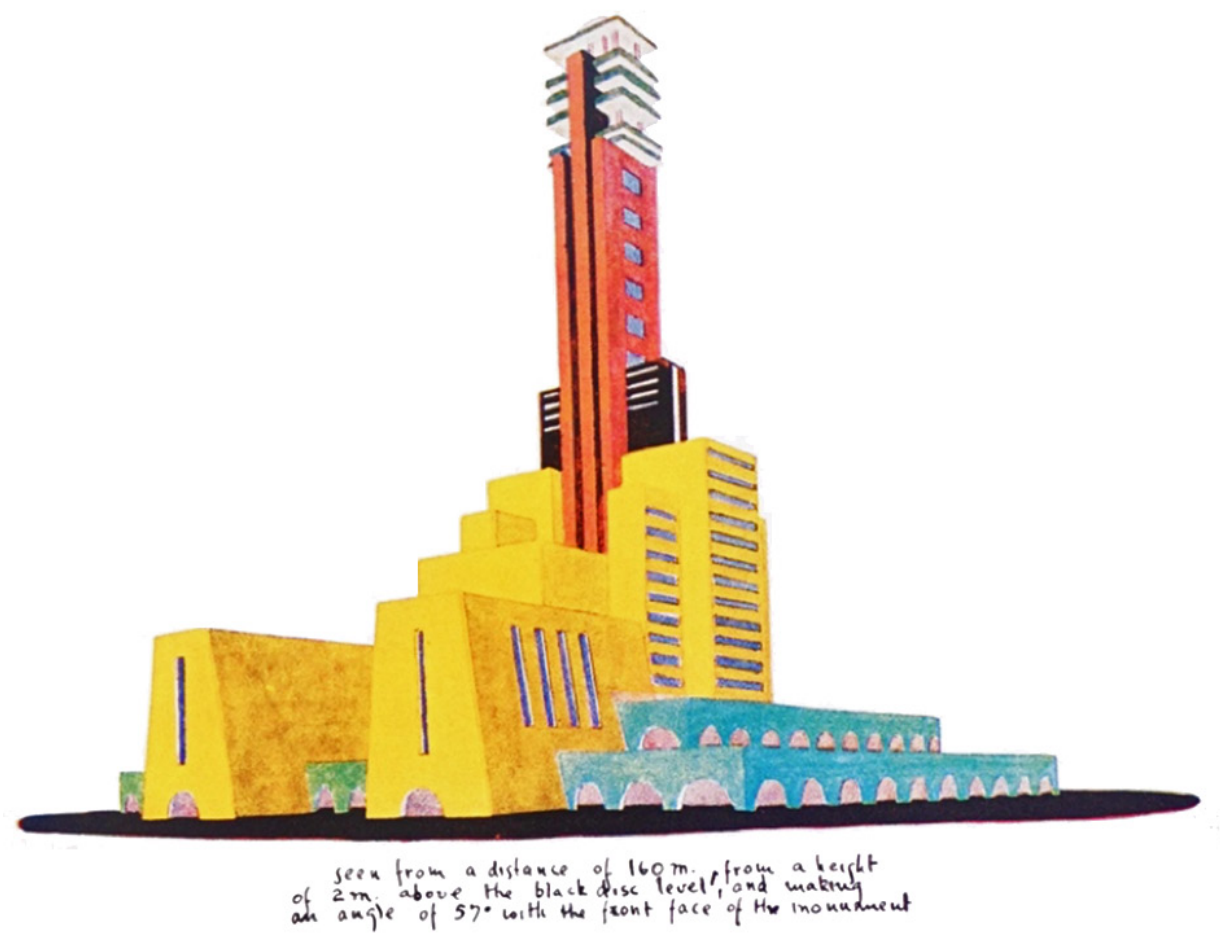

\section{$1: 20$}

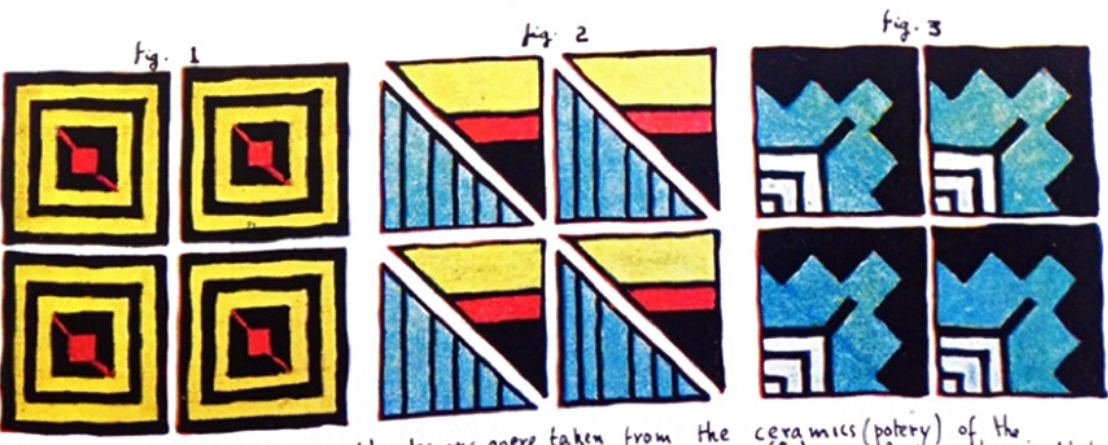

Desgn for ceramic floors: the designs were taken from the ceramics (potery of the ing photo raple)

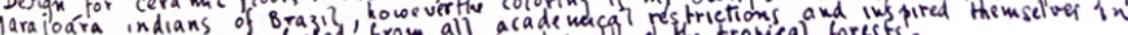

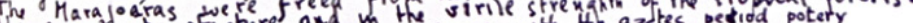

tre simplecity of nature and $\mathrm{m}$ the sance with the aztes pediod potery

me desigen in fegl 1 Thas a stroug 
A série de artigos intitulada "Arquitetura Colonial", foi publicada alguns meses depois de "Arquitetura Moderna", onde o crítico trabalhou sobre o projeto "Efficacia". Nela, Mario de Andrade parece antes se indagar sobre o sentido de se buscar, naquele tempo, um estilo nacional na arquitetura, do que propriamente discorrer sobre o estilo neocolonial que caminhava para ocupar este lugar no contexto brasileiro. Para o poeta, a arquitetura moderna, seguindo a tendência da "sociedade humana" para o universalismo da época, era a única vertente da arte que havia encontrado uma solução de fato internacional, porque até então não havia adquirido o caráter de expressão nacional em "terra nenhuma", e exatamente isto fazia dela a "mais socialmente avançada e a mais satisfatoriamente humana de todas as artes" (ANDRADE M., 1928b). Avançada, porque internacional e destacada do caráter étnico, e humana, porque anônima e liberta do individualismo. Por este aspecto Mario de Andrade chega a aproximar a arquitetura moderna da manifestação folclórica. Em ambas, a mais "avançada" e "erudita"; e a mais "primária" e "fatal", coincidem quando há "presença do ser humano com abstenção total da individualidade" (ANDRADE M., 1928d). Tal aproximação sugere, assim como em Carvalho, uma noção de progresso capaz de reaver as dinâmicas de um mundo pré-burguês. Diante disto, a ideia de uma arquitetura nacional assumiria um cunho separatista e arriscadamente "desumano, anti-social e necessariamente arara" porque trabalhado sobre o falso.

A argumentação do poeta é de inegável pertinência e como um crítico da "atualidade do momento histórico" (ANDRADE M., 1928b) era tendencioso à afirmação do moderno, porém sempre optava pela cautela. Como tal, ponderava que a arquitetura moderna não havia se generalizado ao ponto de se firmar como traço estético da época, apesar de já ser internacional. Além das muitas casas construídas, eram poucos os exemplares significativos de edifícios que pudessem afirmar que o estilo se "normalizaria". Sugere, além disso, que talvez pelo caráter primário e combativo de sua emergência, as obras "teóricas" da arquitetura moderna fossem capazes de sustentar a ausência do individualismo autoral e do fator étnico, que à Mario de Andrade eram tão "comoventes". O poeta acreditava que o característico do anonimato e do universalismo se perderia com o passar do tempo e sua transformação em norma. Assim, seria válida e pertinente a busca por "elementos da constância arquitetônica brasileira" (ANDRADE M., 1928c), pois era fundamental ajustar a força da influência internacional à "atualidade psico-social" (ANDRADE M., 1928c).

Esta tendência "universal" quando aporta em terras brasileiras se confronta com nacionalismos e regionalismos já existentes, o neocolonial um deles. Não que fossem expressões liberadas de modelos europeus importados anteriormente (como o colonial português, o academicismo, o parnasianismo). Mario de Andrade compreendeu que tal encontro fez com que os artistas modernos pensassem a dualidade do nacionaluniversal por caminhos novos e mais livres ao meditar sobre a realidade brasileira, mas que fatalmente alguns deles caminharam ao extremo de fazer coincidir a própria realidade individual com a imagem nacional. Outros teriam enveredado por uma "patriotada artística" radical 5 . De um jeito ou outro, ora pela coincidência ora pela

5 Mario se refere ao movimento verde-amarelismo, à Escola da Anta e ao Integralismo liderado por Plínio Salgado, um movimento associado ao fascismo, um fascismo à brasileira. exacerbação, uma vez "normalizado e inconsciente" (ANDRADE M., 1928e) o encontro das tendências promoveria a libertação do artista brasileiro. Mario de Andrade só não estava certo, naquele momento, se o que propunham os adeptos do neocolonial viria a funcionar em termos de atualidade nacional verdadeiramente criadora, apesar da validade de seu esforço fundador. 
O poeta também indagava sobre a pertinência de um estilo nacional na arquitetura: "será um bem ou mal" (ANDRADE M., 1928b)? Tal angústia traduz a preocupação de Mario de Andrade com as aspirações, inovações e os desejos que eclodiram com o movimento revolucionário das vanguardas artísticas em 1922. Conseguiriam todos aqueles ensejos revolucionários se realizar, "normalizar" e efetivar uma unificação cultural em relação à ideia de nação, coletiva e impessoal? Seu espírito que andava numa "barafunda tamanha" sobre o assunto, manifestava o otimismo de "terra e civilização moças" que só vê o futuro. Antes de mais nada, ele se interessava pelo que seria afinal a síntese ideal para o país da "aventura". O fato em si de almejar uma síntese, revela a feição reformadora do movimento moderno que, claramente, amplia suas aspirações para além do quadro burguês quando adentra a realidade brasileira em busca do traço nacional. Contudo, jamais chegaram a atingir reais possibilidades de transformações sociais. Os objetivos libertários que agitavam as vanguardas acabaram por continuar a alimentar o modelo burguês e, além disso, posteriormente foram ingredientes dinâmicos para um projeto de modernização, de feição autoritária e elitista, que se desenrolou a partir da assim chamada Revolução de 30 .

Se a perspectiva de integração e generalização veio como resposta aos anseios de renovação do movimento que eclodiu com a Semana de 22, o processo histórico mostrou que na transição de uma fase de atualização estética à outra de nacionalização artística, os ideais modernos adquiriram contornos de projeto ideológico. A arquitetura moderna emerge no contexto de transição e tensiona a passagem da ruptura à normalização do espírito de vanguarda. Em que medida a arquitetura, enquanto "arte política, religiosa e social" (CARVALHO, 1929a), sintetiza tal passagem? Neste sentido, vale se deter sobre o debate travado em torno da exposição da casa modernista de Warchavchik em 1930 entre Mario de Andrade, Flávio de Carvalho e Oswald de Andrade. O debate deflagra as vias pelas quais os contornos ideológicos conclamam a arquitetura em suas especificidades de gênero e se assentam sobre a noção de progresso.

Mario de Andrade segue a mesma linha de pensamento dos artigos anteriores onde eleva a arquitetura a um patamar acima das outras artes por seu caráter de liberação do individualismo criador. "Ninguém se lembra de perguntar quem fez a sublime abside de São Pedro" (ANDRADE M., 1930), isso porque a arquitetura responde à condição de arte útil e ao "determinismo histórico em sua mais alta concepção". Quaisquer gestos que escapassem destes fins, seriam meros plágios erguidos sobre o falso: quando uma obra ganha a expressão da autoria se torna apenas "belas-artes desinteressada" e individualismo artístico, porque falseia seus princípios. Do mesmo modo as feições extemporâneas, isentas de força de legitimidade se resumem a reles falseio, e aqui Mario de Andrade é assertivo: o neocolonial é falso. Então, se naquele tempo falava-se da "casa de Warchavchik", fora em virtude apenas do pioneirismo da construção. Logo mais, com o aparecimento de outras casas "atuais" e a normalização da expressão pela racionalidade construtiva, ela seria como as demais casas modernas, apenas uma arquitetura a "agasalhar eficientemente" o ser humano. À luz do pensamento de Mario, isto significaria que estaríamos de fato a conseguir uma "coisa rara", isto é, "atingir em Arquitetura um estilo próprio". Sem dúvida, há no poeta uma visão idealizada e nostálgica da noção de progresso. 
Depois de dizer que o autor de Macunaíma consegue também ser o "o pior crítico do mundo", Oswald de Andrade não deixa de demonstrar similar otimismo em relação à difusão da arte moderna e sua generalização, de modo que a arte como aquela da casa modernista ocupa "o lugar de vitória no mundo transformado de hoje", ou ainda, é a "despedida de uma época de fúria demonstrativa" que começa na Semana de 22 com o grupo de audaciosos artistas (ANDRADE O., 1930a). A arte moderna se legitima: Anita Malfatti e Brecheret já são encarados seriamente. Mas ao contrário do que postulava Mario, para Oswald, o progresso técnico não anularia a individualidade, já que a técnica não se confunde jamais com expressão. Mesmo que se proliferasse uma arquitetura racionalista por "São Paulo, a América, Sidnei, Jaboticabal e Rouen" não se perderiam os gestos de Warchavchik ou de Le Corbusier. Aliás, tendo o espírito moderno se assentado, a individualidade se assegurava "num sossego bom e esportivo, comercial e vitorioso", afinal "depois de Freud e da 'antropofagia', nada é desinteressado". Oswald, como grande entusiasta do viver a vida, enxergava que o progresso havia encaminhado o século para a plenitude do individual, o "século bendito! [...] século em que a gente faz o que quer"! Se em Mario o progresso assume um tom de regresso ao mundo pré-burguês, em Oswald, não há espaço para o sacrifício do individual.

Já Flávio de Carvalho confronta sobretudo a própria questão da "normalização". Não seria ela a mesma e velha maneira pela qual o progresso fez a arte se liberar? Não teria a norma feito do homem uma "máquina de repetir" (CARVALHO, 1930e), ou ainda, não seria a própria razão de suas "tendências recalcadas"? A arquitetura moderna insurge contra a cópia dos modelos do passado, assim sendo, jamais poderia se acomodar sobre um presente padronizado de repetição, que nada mais é do que o produto do próprio progresso técnico. Progredir para Carvalho era o contrário da norma e do dogma assentado, era a mudança, o movimento e a renovação. Tanto mais, era a condição do homem, sua "fórmula inconsciente" (CARVALHO, 1930g). Logo, não era mérito estar seguro, mas antes, "tatear"; buscar "uma emoção rara que os empolgue", como faz a casa modernista de Warchavchik, quando "pela volúpia ele cria novas formas". Não para idealizar uma síntese, mas porque "satura [o] universo dos ideais"; não que o entusiasmo de gozar a vida fosse em si um problema burguês, mas o homem "vive, pensa e faz com pavorosa rapidez" alimentado por sua curiosidade. Em Flávio de Carvalho, a necessidade de dar corpo a um estilo próprio era uma falsa questão já que recairia novamente na construção de um dogma, quando a hora era de luta por sua destruição.

Todos fazem, eu não faço. Esta é a fórmula única que permite o progresso livre - único processo de se desligar da estandardização, de abandonar a monotonia de repetir sempre, (...) de fecundar o futuro com a energia primitiva. (...) A nova arquitetura, para não cair na monotonia das coisas, precisa ser emotiva e romântica (...) Simbolizar exaltadamente a ideia de vida: mudar. (CARVALHO, 1930g)

Aos olhos do antropófago "a arte e a ciência entram numa nova fase de romantismo emotivo", a despeito de toda racionalidade moderna. A arquitetura, por sua vez, também coloca o novo problema que é exatamente o de uma "função romântica altamente exaltada pelo raciocínio do homem" e, aqui, isto significa uma conjunção de racionalidade e paixão pelo desconhecido que vem a travar a noção de Carvalho sobre o progresso na arquitetura. 
${ }^{6}$ Verbete na contracapa do livro de Flávio de Carvalho, elaborada pelo próprio autor em 1931.
Tais são as razões pelas quais Carvalho supõe que o progresso nos remete às dinâmicas de um mundo pré-burguês. É uma tônica de volta que revela sua preocupação com a necessidade de superação de um sistema social condenado. Mario de Andrade também compartilha desta ideia, muito embora as razões pelas quais ela se dê em cada um deles sejam diversas. No poeta, a busca é pelo traço da impessoalidade, já para o antropófago, é a exaltação da "energia primitiva" em seu modo de liberar o homem dos recalques seculares, bem como de acabar com os tabus do ciclo cristão e com o hábito da repetição. Um repetição pela estandardização faz o homem ser sempre o mesmo, assim como a condição de sua contemporaneidade, dos processos de mecanização e multiplicação.

Não que este homem moderno se liberte por completo dos tabus, o tom em Flávio de Carvalho não é redentor, para ele uma sociedade realmente nova e progressista deve ser regida por uma nova ordem de tabus, justamente porque "o movimento da vida aparecerá de um realismo estonteante e ele compreenderá que viver é raciocinar velozmente e dominar os tabus pela compreensão" (CARVALHO, 1930b). Ora, é por isso que a volúpia da forma, o entusiasmo pelo desconhecido e o gozo lógico "produz[em] no homem a ânsia de demolir e construir modernamente" (CARVALHO, 2001)6. Para Carvalho, a solução arquitetônica moderna não é questão de formalismo, precisa ser coletiva e posta em termos de satisfação lógica e desejo, o que "não significa matar a aventura pessoal na arquitetura" (CARVALHO, 1930c), como esperava Mario de Andrade. Daí a irreverência de suas ideias tão profundamente demolidoras, afinal "outros burgueses virão, e o ciclo continuará eternamente" (CARVALHO, 1930g). O que o antropófago realmente pretende é acabar com a calmaria e arrancar o homem da imobilidade tornando-o sempre mais sensível às forças sugestivas do mundo e fornecendo em troca a sugestibilidade da forma.

A nova arquitetura se impóe dentro da nova alma, sem o dedo do divino mono antropomórfico, sem o passado como enfeite e abandonando mesmo todas as ruínas da decadência patriarcal. As cidades serão erguidas para aguentar uma vida anímica intensa, serão cidades sugestivas, sem a sombra do deus, com uma visão sempre jovem. (CARVALHO, 1932)

\section{Referencias bibliográficas}

AINDA O ATORDOANTE PROJETO " EFFICÁCIA". A justificação das ideias básicas que orientam a sua organização, dentro das modernas concepções de arte. Diário da Noite. São Paulo. 06 de fev. de 1928. Fundo FC/CEDAE.

AMARAL, Aracy. Artes Plásticas na Semana de 22. São Paulo: Ed. 34, 1998

ANDRADE, Mario de. Arquitetura Moderna III. Diário Nacional. São Paulo. 04 de fev. de 1928a. Fundo FC/CEDAE.

Arquitetura Colonial I. Diário Nacional. São Paulo. 23 de ago. de 1928b.

Arquitetura Colonial II. Diário Nacional. São Paulo. 22 de ago. de 1928c.

Arquitetura Colonial III. Diário Nacional. São Paulo. 25 de ago. de 1928d.

Arquitetura Colonial IV. Diário Nacional. São Paulo. 26 de ago. de 1928e.

Exposição duma casa modernista. Considerações. Diário Nacional. São Paulo. 5 de abril de 1930. 
ANDRADE, Oswald de. A Casa Modernista, o pior crítico do mundo e outras considerações. O Jornal. São Paulo. 19 de abril de 1930a.

A cidade do homem nu. Diário da Noite. Rio de Janeiro. 28 de jun. de 1930b. Fundo FC/CEDAE.

Arte e Ciência de habitar. Sob o influxo da civilização mecanizada de nosso tempo: Le Corbusier, o grande reformador da arquitetura, fala-nos sobre o palpitante assunto. Diário da Noite. São Paulo. 24 de out. de 1929. Fundo FC/CEDAE.

As novas tendências da Arquitetura. Casas que se vêem na exposição de Stuttgart. Diário Nacional. São Paulo. 09 de fev. de 1928.

CARVALHO, Flávio de. Experiencia n.2: realizada sobre uma procissão de Corpus-Christi: uma possível teoria e uma experiência. Rio de Janeiro: Nau, 2001.

In: Os ante-projetos do Palácio do Congresso são cópias de estilos antigos. Diário Nacional. São Paulo. 01 de mar. de 1929a. Fundo FC/CEDAE.

Uma análise da exposição de Tarsila do Amaral. Diário da Noite. São Paulo. 20 de set. de 1929b. Fundo FC/CEDAE.

In: A arquitetura numa concepção audaciosa. Jornal do Brasil. Rio de Janeiro. 28 de jun. de 1930a. Fundo FC/CEDAE.

In: Uma tese curiosa. Diário da Noite. Rio de Janeiro. 01 de jul. de 1930b. Fundo FC/ CEDAE.

O que é arquitetura!?.... Verdade Literária. São Paulo. 16 de jul. de 1930c. Fundo FC/CEDAE.

In: O futurismo na arquitetura. O engenheiro Flávio de Carvalho fala da filosofia que inspira sua arte. Diário da Noite. Rio de Janeiro. 26 de jun. de 1930d. Fundo FC/CEDAE.

In: O novo ideal de homem. Correio da Manhã. São Paulo. 26 de jun. de 1930e. Fundo FC/CEDAE.

In: Como terminou o primeiro dia do congressistas latino-americanos em visita a São Paulo. Diário da Noite. São Paulo. 05 de jul. de 1930f. Fundo FC/CEDAE.

A Casa Modernista Warchavchik. Diário da Noite. São Paulo. 08 de abril de 1930g. Fundo FC/CEDAE.

Uma concepção da cidade de amanhã. Diário da Noite. Rio de Janeiro. 17 de mar. de 1932. Fundo FC/CEDAE.

JEANNERET, Charles-Edouard [LE CORBUSIER]; OZENFANT, Amadeé. Depois do cubismo. São Paulo: Cosac Naify, 2005.

LE CORBUSIER. In: Arte e Ciência de habitar. Diário da Noite. São Paulo. 24 de out. de 1929. Fundo FC/CEDAE. 